Н. В. Недзвецька, Н. І. Ташевська

Дніпропетровська державна медична академія Дніпропетровський національний університет ім. Олеся Гончара

\title{
ЕФЕКТИ МЕЛАТОНІНУ НА КОГНІТИВНІ ПРОЦЕСИ ТА СТАН АСТРОГЛІЇ У ЩУРІВ 3 ЕКСПЕРИМЕНТАЛЬНИМ ДІАБЕТОМ
}

Досліджено протекторну дію хронічного введення мелатоніну на розвиток пізнавального дефіциту у стрептозотоцин-діабетичних щурів. Виявлено гальмування розвитку астрогліозу та пізнавального дефіциту у групі тварин, які отримували ін'єкції мелатоніну. Отримані результати свідчать на користь того, що мелатонін може попереджати розвиток пізнавального дефіциту у діабетичних тварин через зниження рівня оксидативного стресу та гальмування розвитку астрогліозу.

\section{Н. В. Недзвецкая, Н. И. Ташевская}

Днепропетровская государственная медицинская академия Днепропетровский национальный университет им. Олеся Гончара

\section{ЭФФЕКТЫ МЕЛАТОНИНА НА КОГНИТИВНЫЕ ПРОЦЕССЫ И СОСТОЯНИЕ АСТРОГЛИИ У КРЫС С ЭКСПЕРИМЕНТАЛЬНЫМ ДИАБЕТОМ}

Исследовано протекторное действие хронического введения мелатонина на развитие познавательного дефицита у стрептозотоцин-диабетических крыс. Выявлено торможение развития астроглиоза и познавательного дефицита в группе животных, которые получали инъекции мелатонина. Полученные результаты свидетельствуют в пользу того, что мелатонин может предупреждать развитие познавательного дефицита у диабетических животных путем снижения уровня оксидативного стресса и торможения развития астроглиоза.

\author{
N. V. Nedzvetskaya, N. I. Tashevskaya \\ Dnipropetrovsk State Medical Academy \\ Oles' Gonchar Dnipropetrovsk National University
}

\section{EFFECTS OF MELATONIN ON COGNITIVE PROCESSES AND ASTROGLIA STATE IN RATS WITH EXPERIMENTAL DIABETES}

There was investigated protective effect of chronic melatonin injection on the development of cognitive deficit in rats with streptozotocine induced diabetes. There were observed decrease of astrogliosis and of cognitive deficit in animals that were injected with melatonin. Presented results are evidence that melatonin can prevent the development of cognitive deficit in diabetic animals by decreasing oxidative stress level and astrogliosis inhibition.

\section{Ветуп}

Діабет (Diabetes mellitus) - захворювання, що характеризується гіперглікемією в результаті дефіциту секреції інсуліну, ефективності дії цього гормона або спільного впливу цих факторів. Діабет часто супроводжується порушеннями пізнавальної актив- 
ності, пізнавальним дефіцитом і підвищеним ризиком розвитку деменцій, особливо в літньому віці [9]. Відомо, що при патологічних станах, пов'язаних із нейродегенеративними та віковими змінами, посилюється генерація активних форм і продуктів кисню, нервові ж клітини надзвичайно чутливі до оксидативного стресу [6]. Ці спостереження підтверджують уявлення про те, що мнестичні дисфункції значною мірою пов'язані з розладом метаболізму глюкози та розвитком оксидативного стресу в клітинах головного мозку.

Мелатонін, гормон, що продукується епіфізом, здатний активно зв'язувати радикали атомарного кисню, супероксидні та пероксидні радикали та стимулювати активність деяких антиоксидантних ферментів [14]. В експериментальних моделях діабету, гіперглікемії та пригнічення утилізації глюкози спостерігаються метаболічні порушення в нейронах і гліальних клітинах [2]. Такі порушення, у свою чергу, можуть бути причиною швидкого розвитку нейродегенеративних змін.

Передбачається, що структурна основа формування умовних рефлексів, процесів навчання та пам'яті - модифікації міжклітинних контактів у ЦНС [11]. До реорганізації синапсів залучаються не лише нейрони, а також гліальні клітини. Визнаним маркером астроглії є гліальний фібрилярний кислий білок (ГФКБ).

У наших експериментах вивчено вплив уведення мелатоніну на характеристики процесу навчання щурів із СТЗ-індукованим діабетом і експресію та поліпептидний склад ГФКБ у ряді структур головного мозку таких тварин.

\section{Матеріал і методи досліджень}

Експерименти проводили на щурах лінії Вістар (статевозрілі самці, вік 1416 тижнів). Тварини розділені на три групи $(n=8)$. Тваринам контрольної групи вводили фізіологічний розчин. Щурам другої та третьої груп інтраперитонеально вводили одноразово 50 мг/кг СТ3, розчиненого в 0,05 М натрійцитратному буфері. Рівень глюкози у венозній крові вимірювали через три доби після ін'єкції СТЗ. Для подальшого дослідження відібрані тварини 3 концентрацією глюкози у венозній крові понад 250 мг/л, що свідчило про розвиток у цих щурів вираженого стану СТЗ-індукованого діабету (далі - СТЗД). Тварини третьої групи щодня після введення СТЗ одержували ін'єкцію 10 мг/кг мелатоніну протягом 21 доби.

Характеристики процесу навчання та формування пам'ятного сліду оцінювали 3 використанням водного тесту Морріса [6]. Фракції цитоскелетних білків одержували 3 тканин гіпокампа, кори великих півкуль і мозочка, як було описано раніше [1]. Білкові фракції розділяли електрофоретично в градієнті поліакриламідного гелю 7,5-17,5 \% [10]. Поліпептидний склад і вміст ГФКБ визначали за допомогою імуноблотингу з використанням моноспецифічної антисироватки [3], вміст загального білка - використовуючи метод Лоурі в модифікації Міллера [12]. Визначення відносної інтенсивності поліпептидних зон проводили за допомогою комп'ютерної обробки сканованих результатів імуноблотингу. Кількісний аналіз ГФКБ проводили шляхом порівняння інтенсивностей забарвлення відповідних поліпептидних зон між експериментальними та контрольними пробами, віднесених до кількості загального білка у фракціях.

Одержані дані опрацьовували методами математичної статистики для малих вибірок. Відносний вміст ГФКБ виражали у вигляді середньої величини \pm стандартна похибка середньої, достовірну різницю між групами оцінювали із застосуванням $t$-критерію Стьюдента $(p<0,05)$. 


\section{Результати та їх обговорення}

Процес навчання та формування пам'ятних слідів в експериментальних групах щурів оцінювали у ході виконання водного тесту Морріса протягом 7 діб. Час, який витрачали тварини для виявлення підводної платформи, погресивно скорочувався (рис. 1). На сьомий день щури контрольної групи виконували завдання тесту за $8,0 \pm 1,6$ с. Щури другої СТЗД - за 23,6 $\pm 4,1$ c, тобто витрачали майже втричі більше часу $(p<0,001)$. Настільки істотні відмінності свідчать про різко виражений пізнавальний дефіцит у тварин з експериментальним діабетом (СТЗД).

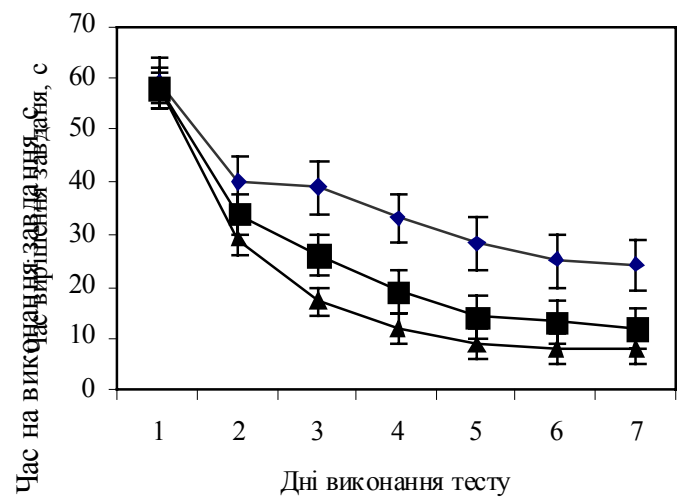

Рис. 1. Результати виконання щурами контрольної $(\Delta)$,

СТЗД (৩) та СТЗД + мелатонін ( $\square$ ) груп тесту Морріса

СТЗД щури, що отримували щоденні ін'єкції мелатоніну, витрачали на пошуки платформи в середньому $11,8 \pm 2,3$ с. Цей показник був удвічі меншим порівняно 3 другою групою тварин. Міжгрупові відмінності показників при порівнянні груп 2 і 3 були високодостовірними $(p<0,01)$ (див. рис. 1$)$. У такий спосіб курсове введення мелатоніну у фармакотерапевтичних дозах істотно перешкоджало розвитку пізнавального дефіциту у тварин з СТЗД.

Рівень ГФКБ і поліпептидний склад визначали у трьох білкових фракціях (розчинній, цитоскелетній і Тритон X-100-екстрагованій) гіпокампа, кори великих півкуль i мозочка. Значне збільшення вмісту розчинної форми ГФКБ виявлене в усіх трьох відділах мозку $(p<0,01)$. У мозку щурів через 21 добу після ін'єкції СТЗ виявлене підвищення вмісту деградованих поліпептидів 40-47 кДа в усіх досліджених фракціях. Найінтенсивніші продукти деградації цитоскелетної фракції ГФКБ (35-37 кДа) виявлені в мозочку та гіпокампі групи діабетичних щурів (рис. 2). У цих відділах виявлене збільшення вмісту ГФКБ у тритоновій фракції $(p<0,01)$, цитоскелетній $(p<0,05)$, а також загального вмісту ГФКБ $(p<0,001)$ порівняно з контрольною групою.

Збільшення деградації ГФКБ у ході астрогліозу може бути результатом дегенеративних ефектів оксидативного стресу та відображає загальні риси метаболічного розладу в астрогліальних клітинах при СТЗ-індукованому діабеті. Значні зміни вмісту та поліпептидного складу білка гліальних філаментів свідчать про інтенсивні цитоскелетні перебудови. Інтенсивний фібрилогенез - головний показник реактивної відповіді астроцитів на нейрональне пошкодження. 


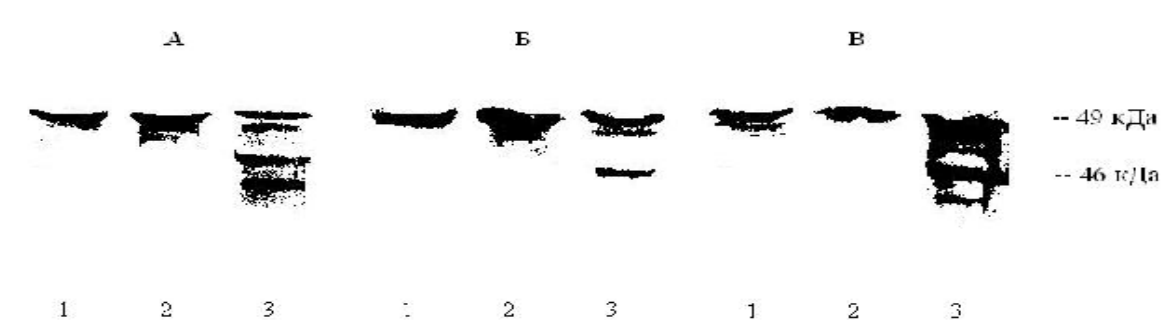

Рис. 2. Імуноблотинг цитоскелетних фракцій ГФКБ

із мозку контрольних (1), СТЗД (2) та СТЗД+мелатонін (3) груп щурів

Істотні відмінності поліпептидного складу та вмісту ГФКБ виявлені також між другою групою щурів із СТЗД і третьою групою тварин із СТЗД, що отримували щоденні ін'єкції мелатоніну. Відносний вміст ГФКБ у групи щурів із СТЗД, що отримували ін'єкції мелатоніну, був достовірно знижений порівняно з групою СТЗД тварин. У такий спосіб уведення мелатоніну перешкоджає розвитку оксидативних пошкоджень, які викликають надмірну експресію гліальних проміжних філаментів у мозку щурів із СТЗД.

Патогенез діабетичної енцефалопатії - багатофакторний - поки залишається не цілком зрозумілим. Вважається, що діабет асоційований з енцефалопатією, яка характеризується повільним розвитком і поступово приводить до клінічно вираженого пізнавального дефіциту. Отримані результати водного тесту Морріса вказують на те, що щури із СТЗД набагато повільніше адаптують поведінкову стратегію у виборі вірного варіанта, ніж тварини контрольної групи.

Стан гіперглікемії стимулює переключення клітинного метаболізму на «поліольний шлях». Підвищення рівня сорбітолу веде до змін активності протеїнкінази $C$. Надлишок глюкози також відбивається на кальцієвому гомеостазі. Загалом це призводить до дисбалансу генерації та видалення реактивних сполук $O_{2}$ і виникнення оксидативного стресу [5]. Розвиток оксидативного стресу може бути зумовлений двома основними причинами - активацією аутооксидативних процесів у результаті підвищення рівня глюкози та зниженням рівнів ендогенних антиоксидантів.

Один 3 основних біохімічних механізмів дії мелатоніну на клітини - антиоксидантний [14]. Погіршення пізнавальної та моторної функції корелює з оксидативними молекулярними ушкодженнями в різних відділах мозку [16]. Хронічне уведення мелатоніну знижує пізнавальний дефіцит і зменшує амнестичний ефект [2]. Недавно показано, що мелатонін поліпшує короткочасну пам'ять і впливає на процес збереження надбаних навичок [1].

Курс щоденних ін'єкцій 10 мг/кг мелатоніну щурам третьої групи протягом трьох тижнів у нашому експерименті забезпечував достовірне зниження часу виконання водного тесту Морріса. Таким чином, мелатонін може перешкоджати розвиткові пізнавального дефіциту в мозку діабетичних щурів. Дія мелатоніну на нервові клітини опосередкована специфічними мелатоніновими рецепторами, що присутні у цій тканині [13]. Передбачається, що механізм протективної дії мелатоніну на виживаність нейронів опосередкований його дією на гліальні клітини [4]. Показано, що астрогліальні клітини мають надзвичайно глибокий ефект на головні нейрональні функції та інтегративні процеси в нервовій системі. Астроцити мають фізіологічні та метаболічні властивості, важливі для нейронального розвитку й інтеграції мозкових функцій. Гліальні клітини експресують широкий спектр нейротропних факторів і $є$ головними протекторами нейронів проти нейротоксичного впливу вільних радикалів. 
Глія має вирішальне значення для виживання нейронів в умовах оксидативного стресу. Глутатіонпероксидаза виявляється переважно в астроцитах, які також мають вищий вміст глутатіону відновленого, ніж нейрони [15].

Порушення астроцитарного транспорту метаболітів та сигнальних молекул може бути причиною модуляції взаємодії великої кількості астроцитів, нейронів і ендотеліальних клітин, що, у свою чергу, відбивається на функціонуванні мозку за умов діабету [8]. На важливу роль астроцитів та нейроваскулярних елементів вказують також результати останніх досліджень формування астроцитарного рубця в мозку діабетичних щурів [7].

Виявлені в нашому експерименті зміни цитоскелетного маркера астроцитів індукуються щільно зв' язаними метаболічними процесами гліальних клітин і нейронів. Це відбивається на процесах нейрональної пластичності, що, у свою чергу, вважається структурною основою процесів навчання та пам'яті. Цитоскелетні перебудови, подібні до спостережених у нашому експерименті, можуть бути частиною процесу формування пам'яті. 3 огляду на раніше отримані результати можна припустити, що даний гормон активно залучається до пластичних перебудов синаптичних контактів у зрілій нервовій системі при метаболічних порушеннях [2].

\section{Висновки}

Хронічне введення мелатоніну у фармакотерапевтичних дозах може помітно модулювати експресію ГФКБ і розвиток астрогліозу в мозку щурів з експериментальним діабетом. Скорочення часу виконання щурами із СТЗД завдань в умовах водного просторового тесту дозволяє припустити вплив мелатоніну на нейрональну пластичність $i$ пізнавальні процеси. Результати демонструють ефективність мелатоніну в попередженні розвитку пізнавального дефіциту у щурів із СТзД і підтверджують його потенційну можливість використання при вікових нейродегенеративних патологіях із метою зниження оксидативного стресу та пізнавального дефіциту.

\section{Бібліографічні посилання}

1. Недзвецкий В. С. Влияние мелатонина на познавательную способность и экспрессию молекулы адгезии нервных клеток NCAM при стрептозотоцин-индуцированном диабете / В. С. Недзвецкий, П. А. Неруш, С. В. Кириченко // Neurophysiology / Нейрофизиология. 2003. - T. 35, № 6. - C. 463-469.

2. Baydas G. Altered expression of NCAM in hippocampus and cortex may underlie memory and learning deficits in rats with streptozotocin-induced diabetes mellitus / G. Baydas, V. S. Nedzvetskii, P. A. Nerush // Life Sci. - 2003. - Vol. 73. - P. 1907-1916.

3. Baydas G. Increase of glial fibrillary acidic protein and S-100B in hipocampus and cortex of diabetic rats: Effects of vitamin E / G. Baydas, V. S. Nedzvetskii, M. Tuzcu // European Journ. of Pharmacol. 2003. - Vol. 462. - P. 67-71.

4. Baydas G. Altered glial acidic protein content and its degradation in the hippocampus, cortex and cerebellum of rats exposed to constant light: reversal by melatonin / G. Baydas, R. J. Reiter, V. S. Nedzvetskii // J. Pineal Res. - 2002. - Vol. 33. - P. 1-6.

5. Biessels G. J. The calcium hypothesis of brain aging and neurodegenerative disorders: Significance in diabetic neuropathy // Life Sci. - 1996. - Vol. 59. - P. 379-387.

6. Coyle J. T. Oxidative stress, glutamate, and neurodegenerative disorders / J. T. Coyle, P. Puttfarcken // Science, - 1993, - V. 262, № 1, - P. 689-695.

7. Frontczak-Baniewicz M. Ultrastructural and immunochemical studies of glial scar formation in diabetic rats / L. Struzynska, J. Andrychowski, J. Opertowska et al. // Acta Neurochir. Suppl. - 2010. Vol. 106, N 1. - P. 251-255. 
8. Hyperglycaemia and diabetes impair gap junctional communication among astrocytes / G. K. Gandhi, K. K. Ball, N. F. Cruz, G. A. Dienel // ASN Neuro. - 2010. - Vol. 5, N 2. - P. 130-136.

9. Gispen W. H. Cognition and synaptic plasticity in diabetes mellitus / W. H. Gispen, G-J. Biessels // Trends Neurosci. - 2000. - Vol. 23, N 2. - P. 542-549.

10. Laemmli O. H. Cleavage of structural proteins during the assembly of the head of bacteriophage T4 // Nature. - 1970. - Vol. 227, N 1. - P. 243-246.

11. Litvin O. O. Mechanisms of memory reorganization during retrieval of acquired behavioral esperiance in chiks: the effects of protein synthesis inhibition in the brain / O. O. Litvin, K. V. Anokhin // Neurosci Behav. Physiol. - 2000. - Vol. 30, N 6. - P. 671-678.

12. Miller G. L. Protein determination for large numbers of samples // Anal. Chem. - 1959. - Vol. 31, N 5. - P. 964-966.

13. Noslean O. Comparative pharmacological studies of melatonin receptors MT1, MT2 and MT3/QR2. Tissue distribution of MT3/QR2 / O. Noslean, J. P. Nicolas, F. Klupsh // Biochem. Pharmacol. 2001. - Vol. 61, N 11. - P. 1369-1379.

14. Free radical-mediated molecular damage. Mechanisms for the protective actions of melatonin in central nervous system / R. J. Reiter, D. Acuna-Castroviejo, D. X. Tan, S. Burkhardt // Ann. of the N. Y. Acad. of Sci. - 2001. - Vol. 939. - P. 200-215.

15. Ridet J. L. Reactive astrocytes: Cellular and molecular cues to biological function / J. L. Ridet, S. K. Malhotra, A. A. Privat // Trends Neurosci. - 1997. - Vol. 20, N 12. - P. 570-577.

16. Sharma M. Intracerebroventricular injection of streptozotocin in rats produces both oxidative stress in the brain and cognitive impairment / M. Sharma, Y. K. Gupta // Life Sci. - 2001. - Vol. 68. P. 1021-1029.

17. Teunissen C. E. Behavioural correlates of striatal glial fibrillary acidic protein in the 3-nitropropionic acid rat model: Disturbed walking pattern and spatial orientation / C. E. Teunissen, H. W. Steinbusch, M. Angevaren // Neurosci. - 2001. - Vol. 105, N 1. - P. 153-167.

Надійшла до редколегії 04.07.2010 